JAMES BERTRAND GORDON-Russeru, retired Consultant Poychiatrist, Wick Cottage, 16 Over Lane. Almondsbury, Bristol.

JAN TBODOR LEYBERG, retired, 1 Old Globe Cottages, Cox Green Road, Egerton, Bolton.

DEIRDRE Paurusy, retired, The Stockwell Centre, Colchester, Esecex.

DAvid Perr, Consultant Psychtatrist, 316 Roxdale Gardens,
Loys Ellis Avenue, Lower Houghton, Johannesburg. South Afitca.

ERwnN Rngem, Professor of Psychiatry and Neurology. Untveraity of Vienna, Austria.

BAranRa Shorvon, formerty Consultant Pyychiatrist. 15 Stamford Brook Road, London W6.

Jorn Wunn WishnRT, formerly Medical Superintendent, St Saviour's Hoopltal, Jersey. Channel Islands.

\title{
Miscellany
}

\section{Postgraduate degree on research into mentally ill disordered offenders}

The Mental Health Foundation's Committee on Mentally Disordered Offenders is inviting applications from professional practitioners who have a special interest in research into mental health and offending behaviour and who wish to take a postgraduate degree to equip them for research in this field. A maximum of $\$ 10,000$ will be awarded which will include untversity fees and student expenses. Application forms can be obtained by writing to Caroline Newman, Senior Projects Officer, The Mental Health Foundation, 37 Mortimer Street, London W1N 8JU. The closing date for completed applications is 31 January 1995. The award will be made in March 1995.

\section{New diploma for health carers}

Rampton Hospital has recently launched a diploma level course in behavioural studies which has been validated and approved by
Sheffield Hallam Untversity. Other courses recently launched by Rampton Hospital include a diploma in management of the mentally disordered offender and a diploma in care and management of suicidal and parasuicidal behaviour. Further information is available from the Staff Education Centre, Rampton Hospital, Retford, Nottinghamshire DN22 OPD.

\section{New publications}

Promoting Care and Justice: report of the Mental Health Foundation's regional conferences on improving services for mentally disordered offenders has recently been published, price $\$ 9.50$.

Booklets entitled Understanding Childhood Distress and How to Assert Yourself are available from MIND Publications, Granta House, 15-19 Broadway, London E15 4BQ. Each costs 45p, plus a large stamped addressed envelope. 